\title{
PEMETAAN POTENSI LIMBAH TANAMAN PANGAN SEBAGAI PAKAN MENDUKUNG PENINGKATAN POPULASI SAPI POTONG DI KABUPATEN MALANG
}

\author{
Fitria Nur Aini, Sad Likah, dan Nurlaili \\ Jurusan Peternakan Politeknik Pembangunan Pertanian Malang, Malang-Jawa Timur \\ e-mail: nurolaini12@gmail.com
}

\begin{abstract}
ABSTRAK
Kabupaten Malang sebagai salah satu daerah di Jawa Timur memiliki potensi cukup besar untuk pengembangan populasi ternak sapi potong. Salah satu permasalahan yang dihadapi peternak di Kabupaten Malang adalah fluktuasi hijauan pakan. Pemaanfaatan limbah tanaman pangan sebagai pakan hijauan menjadi alternatif pemenuhan kebutuhan nutrisi ternak. Penelitian ini memetakan potensi jerami padi, jerami jagung, jerami kedelai, jerami kacang tanah, jerami ubi kayu dan jerami ubi jalar sebagai sumber hijauan pakan untuk mendukung peningkatan populasi sapi potong. Potensi ditentukan berdasarkan kapasitas tampung wilayah per kecamatan berdasarkan produksi bahan kering (BK), protein kasar (PK) dan total digestible nutrient (TDN). Hasil menunjukkan bahwa kecamatan Donomulyo, Singosari dan Kepanjen memiliki potensi paling besar dalam meningkatkan populasi sapi potong rata-rata sebanyak 35.814 ekor/tahun.
\end{abstract}

Kata kunci: jerami, Kabupaten Malang, populasi, sapi potong

\section{MAPPING THE POTENTIAL OF FOOD CROP BY-PRODUCTS AS FEED TO SUPPORT THE INCREASING OF BEEF CATTLE POPULATION IN MALANG DISTRICT}

\begin{abstract}
Malang Regency as one of regions in East Java has a large potential for the development of beef cattle population. One of the problems faced by breeders in Malang Regency was the fluctuation of forage. Using food crop by-products as feed becomes an alternative to meet the nutritional needs of livestock. This study mapped the potential of rice straw, corn straw, soybean straw, peanut straw, cassava straw and sweet potato straw as a source of feed to support the increasing of beef cattle population. The potential was determined based on the capacity of area per district due to the production of dry matter, crude protein and total digestible nutrients. The results showed that Donomulyo, Singosari and Kepanjen sub-districts had the greatest potential in increasing the population of beef cattle in average by 35.814 heads per year.
\end{abstract}

Key words: beef cattle, Malang Regency, population, straw

\section{PENDAHULUAN}

Sapi potong merupakan komoditas ternak yang penting dan sering dijadikan sorotan objek kebijakan pemerintah karena berperan penting dalam pemenuhan kebutuhan protein hewani (dalam hal ini daging) masyarakat Indonesia. Produksi daging sapi sebanyak 496.302 ton per tahun menduduki urutan kedua terbesar setelah daging ayam ras pedaging yakni 2.144.013 ton per tahun. Produksi ini turut menyumbang pemenuhan kebutuhan daging di dalam negeri sebesar $13,82 \%$. Pertumbuhan produksi daging sapi nasional dalam beberapa tahun terakhir cukup rendah yakni sekitar 2,27\% (BPS, 2018). Sementara di lain hal jumlah penduduk Indonesia terus meningkat yakni dengan laju pertumbuhan $1,19 \%$ atau dengan jumlah penduduk sebanyak 255.461.700 jiwa (BPS,
2013). Peningkatan jumlah penduduk tentu akan menyebabkan terjadinya peningkatan kebutuhan daging juga. Kejadian ini perlu diantisipasi salah satunya melalui upaya peningkatan populasi ternak sapi.

Jawa Timur merupakan provinsi dengan jumlah populasi sapi potong tertinggi di Indonesia, yakni sebanyak 4.657.457 ekor atau 27,32\% dari populasi nasional (BPS, 2018). Kabupaten Malang sebagai salah satu daerah di Jawa Timur memiliki potensi cukup besar untuk pengembangan populasi ternak sapi potong. Selain karena faktor agroklimat, pasar, dan kultur masyarakat yang sesuai, Kabupaten Malang juga memiliki populasi sapi potong cukup besar dibandingkan kabupaten lainnya. Berdasarkan data BPS (2017), Kabupaten Malang berada pada peringkat kelima jumlah populasi sapi potong terbesar yakni 
sebanyak 234.481 ekor. Potensi ini perlu didukung oleh berbagai aspek, salah satunya pakan. Pakan merupakan faktor terbesar dalam biaya produksi usaha peternakan. Salah satu permasalahan yang dihadapi peternak di Jawa Timur termasuk Kabupaten Malang adalah fluktuasi pakan. Kepemilikan lahan tanam hijauan pakan yang terbatas menyebabkan peternak tidak mampu menjaga kontinuitas pemberian pakan pada ternak (Sutanto dan Hendraningsih, 2011). Hal ini diperparah ketika tiba musim kemarau dimana produksi hijauan pakan ternak terutama rumput menurun drastis.

Alternatif lain pemenuhan kebutuhan nutrisi ternak adalah melalui pakan asal limbah tanaman pangan. Hasil samping tanaman pangan adalah bahan pakan lokal yang berpotensi besar dalam mendukung pengembangan peternakan di Indonesia. Hal ini telah banyak diterapkan oleh peternak di Kabupaten Malang dengan cara memberikan tebon jagung sebagai pengganti rumput. Potensi hasil samping pertanian lain cukup banyak misalnya jerami padi, jerami jagung, jerami kacang tanah, bagase tebu, pucuk tebu, dan lain sebagainya (Nugraha et al., 2013; Aini, 2018). Menurut Aini (2018), hasil samping pertanian banyak digunakan sebagai pakan ternak karena jumlahnya yang melimpah, ketersediaan yang kontinyu, dan memiliki kedekatan kultur dalam bertani dan beternak. Pemanfaatan hasil samping tanaman pangan sebagai pakan merupakan bentuk sinergi yang baik untuk meningkatkan produksi pertanian, peternakan, dan perbaikan kualitas lingkungan (Lemaire et al., 2013). Penggunaannya sebagai pakan dapat mensubtitusi rumput atau hijauan pakan sebagai pakan utama. Oleh sebab itu, perlu dilakukan suatu pemetaan terhadap potensi hasil samping tanaman pangan sebagai bahan pakan tambahan.

\section{MATERI DAN METODE}

Penelitian ini dilaksanakan pada bulan November 2019 hingga Juli 2020 di Kabupaten Malang. Data primer diperoleh dari Dinas Tanaman Pangan, Hortikultura dan Perkebunan Kabupaten Malang, sedangkan data sekunder diperoleh dari situs BPS Pusat, BPS Jawa Timur, dan BPS Kabupaten Malang. Data primer dan data sekunder selanjutnya diolah dan dianalisis secara deskriptif dengan tabulasi data, konversi, dan rataan menggunakan Ms. Excel Windows 8.

\section{Penentuan Kepadatan Ternak}

Penentuan kepadatan ternak ditentukan dengan cara membagi jumlah populasi sapi potong dengan luas wilayah (Syamsu, 2006). Kepadatan ternak (KT) dihitung dengan rumus:

$$
\mathrm{KT}\left(\mathrm{e} / \mathrm{km}^{2}\right)=\frac{\text { Populasi ternak }(\mathrm{e})}{\text { Luas wilayah }\left(\mathrm{km}^{2}\right)}
$$

\section{Produksi Limbah Tanaman Pangan}

Produksi limbah tanaman pangan dihitung dengan cara konversi proporsi limbah (bagian) terhadap jumlah produksi tanaman pangan berdasarkan literatur berikut :

Jerami padi (ton/th) $=4,21 \times$ prod. padi (ton/th) (Wulandari, 2015)

Jerami jagung (ton/th) $=1,25 \times$ prod. jagung (ton/ th) (Wulandari, 2015)

Jerami kedelai $($ ton $/$ th $)=0,22 \times$ prod. kedelai (ton/th) (Antorida, 2014)

Jerami kacang tanah $($ ton $/$ th $)=0,79 \times$ prod. kacang tanah (Prawiradiputra dan Lukiwati, 2014) Jerami ubi kayu (ton/th) $=0,20 \times$ prod. ubi kayu (Saragi, 2014)

Jerami ubi jalar (ton/th) $=0,26 \times$ prod. ubi jalar (Antorida, 2014)

\section{Peningkatan Populasi Ternak Sapi Potong (KPPT)}

Penentuan kapasitas peningkatan populasi ternak sapi potong dihitung dari selisih antara daya dukung limbah tanaman pangan dengan jumlah populasi sapi potong. Kapasitas peningkatan populasi ternak sapi potong dihitung dengan rumus berikut :

\footnotetext{
Produksi BK limbah tanaman pangan (ton/th)

$\mathrm{KPPT}=--$ populasi sapi (e/th) Produksi BK limbah tanaman pangan (ton/th)
}

\section{HASIL DAN PEMBAHASAN}

\section{Geografis Wilayah}

Kabupaten Malang terletak di koordinast $112^{\circ} 17^{\prime}-$ $112^{\circ} 57^{\prime}$ Bujur Timur dan $7^{\circ} 44^{\prime}-8^{\circ} 26^{\prime}$ Lintang Selatan. Kabupaten Malang dengan luas wilayah $3530,65 \mathrm{~km}^{2}$ menjadi kabupaten terluas kedua di Jawa Timur setelah Kabupaten Banyuwangi atau sekitar 7,39\% dari luas provinsi Jawa Timur. Kabupaten Malang memiliki populasi terbesar di Jawa Timur dengan jumlah penduduk 2.592.00o jiwa atau 6,56\% dari jumlah penduduk di Jawa Timur. Ibukota Kabupaten Malang terletak di Kepanjen. Rata-rata ketinggian wilayah berada di $637 \mathrm{~m}$ di atas permukaan laut (dpl) atau menjadi wilayah tertinggi keempat di Jawa Timur setelah Bondowoso, Sumenep dan Kota Batu (BPS Jatim 2017).

\section{Keragaan Ternak Sapi Potong}

Populasi ternak sapi potong dalam tiga tahun terakhir (2016-2018) mengalami peningkatan ratarata sebesar $2,47 \%$. Peningkatan populasi ini paling 
tinggi dibandingkan jenis ternak potong lainnya (Tabel 1). Disisi lain, jumlah produksi daging sapi mengalami penurunan rata-rata sebesar -3,14\%. Laju pertumbuhan produksi daging paling besar adalah daging kambing dengan rata-rata laju pertumbuhan sebesar 12,90\% atau $128.460 \mathrm{~kg} /$ tahun (Tabel 1).

Laju pertumbuhan populasi sapi potong yang lebih tinggi dibandingkan laju pertumbuhan produksi daging mengindikasikan bahwa populasi sapi potong masih terkendali dan tidak sampai terjadi kelangkaan. Ilham (2019) menjelaskan bahwa terjadinya kelangkaan sapi potong akibat jumlah pemotongan yang terlalu tinggi ataupun penurunan populasi ternak dapat menyebabkan penurunan sumber daya potensi ternak lokal. Hal ini disebabkan adanya kemungkinan pemotongan ternak unggul sehingga tidak tersisakan untuk pembibitan.

Jumlah populasi sapi di Kabupaten Malang cenderung meningkat, namun disisi lain produksi daging justru mengalami penurunan. Hal ini kemungkinan disebabkan karena adanya penurunan produktivitas ternak yakni persentase karkas daging yang semakin sedikit maupun karena usia ternak potong yang masih muda sehingga jumlah daging yang dihasilkan menjadi lebih sedikit. Ilham (2019) menerangkan bahwa daging sapi adalah salah satu produk peternakan yang perlu mendapatkan perhatian pemerintah. Hal ini dikarenakan pengaruhnya terhadap konsumsi masyarakat dan kecenderungan harga yang terus meningkat.

Tabel 1. Keragaan Ternak Potong di Kabupaten Malang (2016-2018)

\begin{tabular}{lrrrr}
\hline \multirow{2}{*}{ Uraian } & \multicolumn{3}{c}{ Tahun } & \multirow{2}{*}{ r (\%) } \\
\cline { 2 - 4 } & 2016 & 2017 & 2018 & \\
\hline Populasi Ternak (ekor) ${ }^{*}$ & & & & \\
Sapi & 223717 & 234482 & 234761 & 2,47 \\
Kerbau & 1150 & 1164 & 1051 & $-4,25$ \\
Kuda & 861 & 882 & 665 & $-11,08$ \\
Kambing & 248048 & 253209 & 258317 & 2,05 \\
Domba & 33284 & 33776 & 34294 & 1,51 \\
Babi & 13262 & 13581 & 13914 & 2,43 \\
Produksi Daging (kg) ${ }^{* * *}$ & & & & \\
Sapi & 4744740 & 4455243 & 4447040 & $-3,14$ \\
Kerbau & 13120 & 9953 & 12441 & 0,43 \\
Kuda & 33058 & 25755 & 16337 & $-29,33$ \\
Kambing & 984480 & 996225 & 1241400 & 12,90 \\
Domba & 112425 & 107296 & 119840 & 3,56 \\
$\quad$ Babi & 36423 & 27495 & 37699 & 6,30 \\
\hline Keterangan : ${ }^{*}=$ BPS Kab. Malang $(2018),{ }^{* *}=$ & BPS Jatim (2018), r = rata-rata laju \\
pertumbuhan & & & &
\end{tabular}

\section{Kepadatan Ternak Sapi Potong}

Kabupaten Malang terdiri dari 33 kecamatan dengan luas wilayah berkisar antara 35,90-239,49 $\mathrm{km}^{2}$ dan total luas wilayah yakni $2.977,05 \mathrm{~km}^{2}$. Jumlah populasi sapi potong di Kabupaten Malang sebanyak 234.761 ekor. Berdasarkan nilai kepadatan ternak, terdapat 17 kecamatan berstatus sangat padat, 8 kecamaatan berstatus padat, 2 kecamatan berstatus sedang, dan 6 kecamatan berstatus jarang. Populasi ternak tertinggi terdapat di Kecamatan Wajak dengan populasi 21.534 ekor. Kecamatan Wajak juga memiliki kepadatan ternak tertinggi yakni $227,728 \mathrm{e} / \mathrm{km}^{2}$. Sedangkan populasi sapi potong terendah terdapat di Kecamatan Pujon dengan populasi 317 ekor. Kecamatan ini sekaligus memiliki kepadatan ternak sapi potong terendah yakni $2,424 \mathrm{e} / \mathrm{km}^{2}$. Jumlah ternak sapi potong yang cukup rendah disebabkan karena peternak di Pujon sebagian besar merupakan peternak sapi perah. BPS Jatim (2018) menunjukkan bahwa jumlah sapi perah di Pujon tertinggi di Kabupaten Malang yakni 20.416 ekor.

Tabel 2. Kepadatan Ternak Sapi Potong di Kabupaten Malang

\begin{tabular}{|c|c|c|c|c|}
\hline Kecamatan & $\begin{array}{c}\text { Luas } \\
\text { Wilayah } \\
\left(\mathrm{km}^{2}\right)\end{array}$ & $\begin{array}{c}\text { Populasi } \\
\text { Ternak } \\
\text { Sapi Po- } \\
\text { tong (e) }\end{array}$ & $\begin{array}{c}\text { Kepa- } \\
\text { datan } \\
\text { Ternak } \\
\left(\mathrm{e} / \mathrm{km}^{2}\right)\end{array}$ & Status \\
\hline Donomulyo & 192,60 & 16119 & 83,692 & Sangat padat \\
\hline Kalipare & 105,39 & 17541 & 166,439 & Sangat padat \\
\hline Pagak & 90,08 & 10086 & 111,967 & Sangat padat \\
\hline Bantur & 159,15 & 17568 & 110,386 & Sangat padat \\
\hline Gedangan & 130,55 & 21352 & 163,554 & Sangat padat \\
\hline Sumbermanjing & 239,49 & 11838 & 49,430 & Padat \\
\hline Dampit & 135,31 & 10471 & 77,385 & Sangat padat \\
\hline Tirtoyudo & 141,96 & 2018 & 14,215 & Jarang \\
\hline Ampelgading & 79,60 & 347 & 4,359 & Jarang \\
\hline Poncokusumo & 102,99 & 17375 & 168,706 & Sangat padat \\
\hline Wajak & 94,56 & 21534 & 227,728 & Sangat padat \\
\hline Turen & 63,90 & 3351 & 52,441 & Padat \\
\hline Bululawang & 49,36 & 2536 & 51,378 & Padat \\
\hline Gondanglegi & 79,74 & 3792 & 47,555 & Padat \\
\hline Pagelaran & 45,83 & 4547 & 99,214 & Sangat padat \\
\hline Kepanjen & 46,25 & 1807 & 39,070 & Sedang \\
\hline Sumberpucung & 35,90 & 3009 & 83,816 & Sangat padat \\
\hline Kromengan & 38,63 & 1810 & 46,855 & Padat \\
\hline Ngajum & 60,12 & 5304 & 88,224 & Sangat padat \\
\hline Wonosari & 48,53 & 1822 & 37,544 & Sedang \\
\hline Wagir & 75,43 & 6959 & 92,258 & Sangat padat \\
\hline Pakisaji & 38,41 & 2875 & 74,850 & Sangat padat \\
\hline Tajinan & 40,11 & 4598 & 114,635 & Sangat padat \\
\hline Tumpang & 72,09 & 4025 & 55,833 & Padat \\
\hline Pakis & 53,62 & 7672 & 143,081 & Sangat padat \\
\hline Jabung & 135,89 & 5827 & 42,880 & Padat \\
\hline Lawang & 68,23 & 3832 & 56,163 & Padat \\
\hline Singosari & 118,51 & 16265 & 137,246 & Sangat padat \\
\hline Karangploso & 58,74 & 1127 & 19,186 & Jarang \\
\hline Dau & 41,96 & 5705 & 135,963 & Sangat padat \\
\hline Pujon & 130,75 & 317 & 2,424 & Jarang \\
\hline Ngantang & 147,70 & 463 & 3,135 & Jarang \\
\hline Kasembon & 55,67 & 869 & 15,610 & Jarang \\
\hline Kabupaten Malang & 2977,05 & 234761 & 79,310 & \\
\hline
\end{tabular}

Produksi Limbah Tanaman Pangan 
Berdasarkan data yang diperoleh setidaknya ada 6 jenis limbah tanaman pangan yang dihasilkan di Kabupaten Malang, yakni jerami padi, jerami jagung, jerami kedelai, jerami kacang tanah, jerami ubi kayu, dan jerami ubi jalar. Jerami padi menjadi komoditas dengan produksi tertinggi yakni 2.096.412,8 ton bahan segar atau 1.851.132,5 ton bahan kering. Secara umum limbah tanaman pangan memiliki kualitas yang kurang baik karena kandungan protein kasar yang rendah dan serat kasar yang tinggi (Tabel 2).

\section{Limbah Tanaman Pangan sebagai Pakan}

Keenam limbah tanaman pangan memiliki kualitas nutrisi yang berbeda dilihat berdasarkan kandungan proksimat dan TDNnya. Kadar protein kasar berkisar antara 4,2-24,9\%. Jerami padi mengandung protein kasar $(4,2 \%)$ lebih rendah dibandingkan limbah tanaman pangan lainnya (Tabel 2). Hal ini sesuai dengan Zakaria et al. (2013) yang menerangkan bahwa protein kasar jerami padi berkisar antara $6,32-13,21 \%$. Jerami padi juga memiliki kandungan energi paling rendah dilihat berdasarkan kandungan TDN-nya. Sementara itu, jerami ubi kayu memiliki kualitas yang lebih baik yakni dengan kandungan protein kasar 24,9\% dan TDN 61,97\% (Tabel 2). Namun demikian, jerami ubi kayu tidak bisa diberikan dalam jumlah yang terlalu banyak karena kandungan anti-nutrisi di dalamnya. Hijauan pakan ternak yang berasal dari limbah tanaman pangan memiliki kualitas yang sangat bervariasi mulai dari paling rendah seperti jerami padi hingga paling tinggi seperti tanaman kacang-kacangan. Limbah tanaman pangan yang berasal dari tanaman kacang-kacangan bahkan memiliki kualitas yang hampir sama dengan rumput gajah dan leguminosa (Prawiradiputra 2014). Selanjutnya dijelaskan bahwa daya dukung limbah tanaman asal kacang-kacangan dan umbi-umbian untuk ternak sapi di Pulau Jawa berkisr 40,5 juta hingga 125,35 juta satuan ternak (ST) jika tersedia dalam waktu yang sama.

Sapi potong merupakan salah satu jenis ternak yang memiliki kemampuan tinggi dalam memanfaatkan bahan pakan berkualitas rendah seperti jerami sebagai sumber makanannya (Zakaria et al. 2013). Teknologi pengolahan pakan untuk meningkatkan kualitas jerami telah banyak dilakukan seperti teknik fermentasi, amoniasi, penambahan EM4, cracking dan sebagainya. Teknologi pakan yang efisien sangat diperlukan oleh peternak dalam rangka pemanfaatan limbah tanaman pangan sebagai pakan ternak sapi potong.

\section{Kapasitas Peningkatan Populasi Ternak}

Kelangkaan sumber hijauan pakan ternak merupakan salah satu faktor yanag dapat menghambat pertumbuhan populasi ternak sapi potong karena peternak tidak mampu memberikan pakan dalam jumlah yang cukup sesuai kebutuhan ternak. Kalaupun tetap ingin memenuhi hijauan pakan untuk ternaknya peternak terpaksa harus menempuh jarak yang cukup jauh bahkan hingga keluar daerah. Oleh sebab itu perlu adanya suatu pemetaan potensi wilayah untuk meningkatkan efisiensi peternak dalam memperoleh sumber hijauan pakan. Salah satu metode untuk mengetahui potensi suatu wilayah adalah dengan penghitungan kapasitas peningkatan populasi ternak (KPPTR). Menurut Syamsu (2006), KPPTR diperoleh dari selisih antara daya dukung pakan dengan jumlah ternak. KPPTR menggambarkan jumlah ternak yang dapat ditambahkan di suatu wilayah dilihaat berdasarkan ketersediaan pakan.

Penghitungan KPPTR dengan menghubungkan nilai daya dukung limbah tanaman pangan (perkalian antara jumlah produksi dengan kualitas nutrisi) pada Tabel 3 dengan populasi ternak pada Tabel 2, diperoleh hasil sebagaimana tertera pada Tabel 4. Hasil yang diperoleh menunjukkan bahwa Kabupaten Malang masih berpeluang untuk menambahkan populasi sapi potong sebanyak 706.002 ekor/tahun

Tabel 3. Produksi dan Kualitas Limbah Tanaman Pangan (2018)

\begin{tabular}{|c|c|c|c|c|c|c|}
\hline \multirow{2}{*}{ Uraian } & \multicolumn{6}{|c|}{ Limbah Tanaman Pangan } \\
\hline & JP & JJ & JK & JKT & JUK & JUJ \\
\hline \multicolumn{7}{|l|}{ Produksi (ton/th) } \\
\hline Produksi segar & 2096412,8 & 334073,9 & 4427,9 & 643,6 & 40320,9 & 4636,9 \\
\hline Produksi BK & 1851132,5 & 290043,0 & 3793,8 & 558,4 & 33724,4 & 3725,3 \\
\hline \multicolumn{7}{|l|}{ Kualitas (\%) } \\
\hline Bahan kering & 92,8 & 86,82 & 85,68 & 86,76 & 83,64 & 80,34 \\
\hline $\mathrm{Abu}$ & 18,1 & 6,8 & 9,3 & 9,9 & 7,4 & 12,68 \\
\hline Protein kasar & 4,2 & 6,8 & 15,7 & 11,1 & 24,9 & 11,05 \\
\hline Lemak kasar & 1,4 & 1,8 & 4,4 & 1,7 & 6,8 & 3,96 \\
\hline Serat kasar & 35,1 & 30 & 31,2 & 33,7 & 17,7 & 26,98 \\
\hline BETN & 41,2 & 54,6 & 39,4 & 43,6 & 43,2 & 45,33 \\
\hline TDN & 43,40 & 51,56 & 57,10 & 53,40 & 61,97 & 53,09 \\
\hline
\end{tabular}

Keterangan : JP = jerami padi, JJ = jerami jagung, JK = jerami kedelai, JKT = jerami kacang tanah, JUK = jerami ubi kayu, JUJ = jerami ubi jalar. Sumber : Syamsu (2006); feedipedia.org 
Tabel4. Kapasitas Peningkatan Populasi Ternak Sapi Potongdi Kabupaten Malang Tahun2018

\begin{tabular}{|c|c|c|c|c|c|c|}
\hline \multirow{3}{*}{ Kecamatan } & \multicolumn{6}{|c|}{$\begin{array}{c}\text { Kapasitas Peningkatan Populasi } \\
\text { Ternak Sapi Potong }\end{array}$} \\
\hline & \multicolumn{2}{|c|}{ BahanKering } & \multicolumn{2}{|c|}{ TDN } & \multicolumn{2}{|c|}{ ProteinKasar } \\
\hline & Ekor & $\%$ & Ekor & $\%$ & Ekor & $\%$ \\
\hline Donomulyo & 80838 & 11,45 & 50084 & 13,24 & 31898 & 17,83 \\
\hline Kalipare & 30087 & 4,26 & 14137 & 3,74 & 4661 & 2,61 \\
\hline Pagak & 11786 & 1,67 & 4408 & 1,16 & -53 & $-0,03$ \\
\hline Bantur & 17084 & 2,42 & 4689 & 1,24 & -2908 & $-1,63$ \\
\hline Gedangan & -8352 & $-1,18$ & -12689 & $-3,35$ & -15396 & $-8,61$ \\
\hline Sumbermanjing & 3218 & 0,46 & -1835 & $-0,48$ & -4974 & $-2,78$ \\
\hline Dampit & 38739 & 5,49 & 20897 & 5,52 & 9849 & 5,51 \\
\hline Tirtoyudo & 13832 & 1,96 & 8759 & 2,31 & 5396 & 3,02 \\
\hline Ampelgading & 14138 & 2,00 & 9162 & 2,42 & 5989 & 3,35 \\
\hline Poncokusumo & 13592 & 1,93 & 3647 & 0,96 & -2153 & $-1,20$ \\
\hline Wajak & 20111 & 2,85 & 6804 & 1,80 & -643 & $-0,36$ \\
\hline Turen & 35089 & 4,97 & 21379 & 5,65 & 12990 & 7,26 \\
\hline Bululawang & 16616 & 2,35 & 9674 & 2,56 & 5344 & 2,99 \\
\hline Gondanglegi & 27803 & 3,94 & 16518 & 4,37 & 9616 & 5,38 \\
\hline Pagelaran & 22957 & 3,25 & 12884 & 3,41 & 6610 & 3,70 \\
\hline Kepanjen & 49987 & 7,08 & 30895 & 8,17 & 18947 & 10,59 \\
\hline Sumberpucung & 25687 & 3,64 & 15438 & 4,08 & 9166 & 5,12 \\
\hline Kromengan & 26495 & 3,75 & 16128 & 4,26 & 9663 & 5,40 \\
\hline Ngajum & 24351 & 3,45 & 13614 & 3,60 & 7025 & 3,93 \\
\hline Wonosari & 16773 & 2,38 & 9956 & 2,63 & 5704 & 3,19 \\
\hline Wagir & 2282 & 0,32 & -970 & $-0,26$ & -2991 & $-1,67$ \\
\hline Pakisaji & 25419 & 3,60 & 15006 & 3,97 & 8492 & 4,75 \\
\hline Tajinan & 20327 & 2,88 & 11540 & 3,05 & 6191 & 3,46 \\
\hline Tumpang & 24576 & 3,48 & 14921 & 3,94 & 9268 & 5,18 \\
\hline Pakis & 19152 & 2,71 & 9534 & 2,52 & 4007 & 2,24 \\
\hline Jabung & 18003 & 2,55 & 9893 & 2,61 & 4911 & 2,75 \\
\hline Lawang & 17201 & 2,44 & 9913 & 2,62 & 5472 & 3,06 \\
\hline Singosari & 36786 & 5,21 & 17461 & 4,61 & 5429 & 3,04 \\
\hline Karangploso & 24965 & 3,54 & 15373 & 4,06 & 9387 & 5,25 \\
\hline Dau & 1144 & 0,16 & -994 & $-0,26$ & -2163 & $-1,21$ \\
\hline Pujon & 2032 & 0,29 & 1392 & 0,37 & 1090 & 0,61 \\
\hline Ngantang & 11902 & 1,69 & 7516 & 1,99 & 4853 & 2,71 \\
\hline Kasembon & 21380 & 3,03 & 13243 & 3,50 & 8182 & 4,57 \\
\hline $\begin{array}{l}\text { Kabupaten } \\
\text { Malang }\end{array}$ & 706002 & 100 & 378376 & 100 & 178859 & 100 \\
\hline
\end{tabular}

berdasarkan bahan kering (BK), 378.376 ekor/tahun berdasarkan total digestible nutrient (TDN) dan 178.859 ekor/tahun berdasarkan protein kasar.

\section{SIMPULAN DAN SARAN}

Berdasarkan rata-rata nilai kapasitas peningkatan populasi ternak sapi potong, Kecamatan Donomulyo, Kepanjen dan Singosari memiliki potensi paling besar untuk meningkatkan populasi sapi potong rata-rata sebanyak 35.814 ekor/tahun. Sementara itu beberapa kecamatan menunjukkan nilai negatif yang menunjukkan bahwa produksi limbah tanaman pangan tidak cukup untuk memenuhi kebutuhan nutrisi ternak di wilayah tersebut, antara lain Kecamatan Gedangan, Sumbermanjing, Wagir dan Dau.

\section{DAFTAR PUSTAKA}

Aini, F. N. 2018. Aktivitas enzim lignoselulase Paenibacillus sp. serta potensinya dalam meningkatkan ketersediaan nutrien pakan [Tesis]. Bogor (ID) : Institut Pertanian Bogor.

Antorida, D. 2014. Potensi limbah tanaman pangan di Kabupaten Garut Jawa Barat untuk pengembangan budidaya ternak sapi perah [Skripsi]. Bogor (ID) : Institut Pertanian Bogor.

[Badan Pusat Statistik] BPS. 2013. Proyeksi penduduk Indonesia 2010-2035. Jakarta (ID) : BPS.

[Badan Pusat Statistik] BPS. 2018. Produksi daging sapi menurut provinsi 2007-2018. Jakarta (ID) : BPS.

[Badan Pusat Statistik] BPS Jatim. 2018. Penduduk, Laju Pertumbuhan Penduduk, Distribusi Persentase Penduduk, Kepadatan Penduduk, Rasio Jenis Kelamin Penduduk Menurut Kabupaten. Surabaya (ID) : BPS Jawa Timur.

[Badan Pusat Statistik] BPS Jatim. 2018. Produksi Daging Ternak Menurut Kabupaten/Kota dan Jenis Ternak di Provinsi Jawa Timur (kg). Surabaya (ID) : BPS Jawa Timur.

[Badan Pusat Statistik] BPS Kab. Malang. 2018. Luas Wilayah Menurut Kecamatan.. Malang (ID) : BPS Kab. Malang.

[Badan Pusat Statistik] BPS Kab. Malang. 2018. Populasi Ternak Besar per Kecamatan di Kabupaten Malang, 2013-2019 (ekor). Malang (ID) : BPS Kab. Malang.

[Badan Pusat Statistik] BPS Jatim. 2018. Rata-Rata Tinggi Wilayah di Atas Permukaan Air Laut (DPL) Menurut Pos Hujan di Kabupaten/Kota di Provinsi Jawa Timur. Surabaya (ID) : BPS Jawa Timur.

Feedipedia Animal Feed Resources Information System. 2019. Feed categories : plant products/ by-products. INRA CIRAD AFZ and FAO.

Ilham, N. 2019. Kelangkaan produksi daging : indikasi dan implikasi kebijakannya. Jakarta (ID) : Pusat Analisis Sosial Ekonomi dan Kebijakan Pertanian.

Lemaire, G., Franzluebbers A., Carvalho P. C., dan Dedieu, B. 2013. Integrated crop-livestock systems: strategies to achieve synergy between agricultural production and environment quality. Agr Eco Env . xx:xxx-xxx.

Nugraha, B. D., Handayanta, E., dan Rahayu, E. T. 2013. Analisis daya tampung (carrying capacity) ternak ruminansia pada musim penghujan di daerah pertanian lahan kering Kecamatan Semin Kabupaten Gunungkidul. Trop Anim Husbandry. 2(1):34-40.

Saragi, M. P. 2014. Potensi dan kualitas limbah pertanian sebagai pakan di Kabupaten Bandung 
dan Bogor untuk pengembangan budidaya ternak sapi perah [Tesis]. Bogor (ID) : Institut Pertanian Bogor.

Syamsu, J. A. 2006. Analisis potensi limbah tanaman pangan sebagai sumber pakan ternak ruminansia di Sulawesi Selatan [Disertasi]. Bogor (ID) : Institut Pertanian Bogor.

Prawiradiputra, B. R., Lukiwati, D. R. 2014. Pemanfaatan sisa hasil dan ikutan tanaman pangan kacang-kacangan dan umbi-umbian untuk pakan ternak. Proc. Seminar Hasil Penelitian Tanaman Aneka Kacang dan Umbi. 899-907.

Wulandari, D. 2015. Potensi dan ketersediaan limbah pertanian untuk mendukung budidaya sapi potong di Kabupaten Cirebon [Skripsi]. Bogor (ID) : Institut Pertanian Bogor.

Zakaria Y, Novita C. I., dan Samadi. 2013. Efektivitas fermentasi dengan sumber substrat yang berbeda terhadap kualitas jerami padi. Agripet. 13(1): 22-25. 